\title{
Studying the Intensity and Storm Surge Phenomena of Tropical Cyclone Roanu (2016) over the Bay of Bengal Using NWP Model
}

\author{
M. I. Ali ${ }^{1}$, Saifullah ${ }^{1 *}$, A. $\operatorname{Imran}^{2}$, I. M. Syed ${ }^{2}$, M. A. K Mallik ${ }^{3}$ \\ ${ }^{1}$ Department of Physics, Khulna University of Engineering \& Technology, Khulna, Bangladesh \\ ${ }^{2}$ Department of Physics, University of Dhaka, Dhaka, Bangladesh \\ ${ }^{3}$ Bangladesh Meteorological Department, Dhaka, Bangladesh
}

Received 28 July 2019, accepted in final revised form 15 September 2019

\begin{abstract}
Tropical Cyclone (TC) is the most devastating atmospheric incidents which occur frequently in pre-monsoon and the post-monsoon season in Bangladesh. The Bay of Bengal (BoB) is one of the most vulnerable places of TC induced storm surge. The triangular shape of BoB plays an important role to drive the sea water towards the coast and amplify the surges. In this study, minimum central pressure, maximum wind speed and track of TC Roanu are predicted by the WRF model. At the same time, prediction of cyclone induced storm surge for TC Roanu is done by using MRI storm surge model which is conducted by JMA. The input files for this parametric model is provided by using simulated data of WRF model and observed data of IMD. The results are compared with available recorded data of surge height for this cyclone. The differences in simulated output for two different input files are also studied. The maximum surge height from the MRI model is found $3 \mathrm{~m}$ using WRF simulated data and for IMD estimated data the maximum surge height is found $2.5 \mathrm{~m}$. The simulated surge heights are found in decent contract with the available reported data of the storm surges.
\end{abstract}

Keywords: TC; Storm surge; MRI; IMD.

(C) 2020 JSR Publications. ISSN: 2070-0237 (Print); 2070-0245 (Online). All rights reserved. doi: http://dx.doi.org/10.3329/jsr.v12i1.42402 J. Sci. Res. 12 (1), 55-68 (2020)

\section{Introduction}

A low-pressure system and one of the most powerful atmospheric threats which develops in the tropical oceans is familiar as a Tropical Cyclone (TC) in Southeast Asia.

When the wind speed touched the limit of $118 \mathrm{~km} / \mathrm{h}$, then the system is known as a severe tropical cyclone. The month of March-May is known to as pre-monsoon and the month of October-November is known to as post-monsoon season in this area. These two seasons are the period of arising TC, which generated from the Bay of Bengal (BoB). These TCs are seriously responsible for the spoiling of lives and destruction of assets [1$3]$. The resilient winds, rain and storm surges are the leading features for the destruction from land falling cyclones. Among them, the storm surges are the more devastating and

\footnotetext{
*Corresponding author: saifullahphdu@gmail.com
} 
almost all the loss of lives and damages are happens due to this storm surges combined through severe TCs [4]. When the storm surges pass through the east shore of India, Bangladesh, Myanmar, and SriLanka, it displays serious strength. But the sufferings of Bangladesh from storm surges is much higher than the rest of the countries adjoining BoB. Almost two fifth of the effect of the whole storm surges around the world are accepted by Bangladesh. The shallow coastal water, high astrological flows, low-lying islands and satisfactory cyclonic track are the key features for the contribution of disastrous surges in Bangladesh [5-9].

When in extreme wind stress, the atmospheric pressure varies or when the cyclonic winds stirring near the storm, that drive the water to the coastal area, then the storm surge is formed over that region. This storm surges provisionally increases the height of the total water level, generating a gale stream which can overflow massive areas of land [10,11]. Thus any precise forecast, the real-time monitoring and warning of the storm surges associated with the BoB cyclone is of excessive significance to decrease the loss of life and damages to the properties of coastal areas. There are various studies involving to TC simulations. Over the last two decades the different research group made considerable advancement in the field of numerical modelling of the storm surge in BoB $[3,7,8]$. The basic numeric of the numerical storm surge model was changed very little through the recent decades, so these models are very reliable at the present time [11].

Dube et al. [12,13] have introduced mathematical models to understand the vigorous influence of curving coasts and the path of movement of the storm. Sinha et al. [14,15] studied storm surges simulation by a multilevel model over Bangladesh and also established a mathematical model for simulating the storm surges phenomena on the Indian shores neighboring to BoB. Flather [16] has used a numerical model for forecasting tides and storm surges where the regions of the broad sea joined through estuarine channels and intertidal banks. He also found that the exact location of landfall with the timing of 5 hours delayed. As a consequence, the region of maximum water level moves towards the north. Ali et al. [17] considered a study about the interaction among the river discharge, the storm surges and tides in the Meghna river inlet in Bangladesh. They have used a two-dimensional vertically integrated numerical model and observed that the storm surges acts in opposition to the river discharge. As-Salek $[18,19]$ observed negative surges in the Meghna estuary and its duration is about 4-6 h. These negative surges reduce maritime aquaculture connections and show extraordinary sensitivity to the astrological tides and to the circulation track of a cyclone in the region. Jakobsen [20] identified that 17 severe cyclonic storms hit the coastal area of Bangladesh during 1960-2000 and found that the maximum simulated surge level is $12.5 \mathrm{~m}$ (PWD), which gives the very good agreement with the observations. Debsarma [21] has calculated time sequence of storm surges due to different cyclones and a 3D vision of the highest surges has also been completed through landfall. Shaji et al. [22] studied about the storm surges phenomena in the north Indian sea. The study exposes that almost $40 \%$ of losses due to storm surges happened in Bangladesh and also suggested that, to improve the storm surge simulation the quality of model inputs and parameters must be increased. Zheng et al. [23,24] 
considered an attempt to simulate the storm surge associated with different typhoons along the Jiangsu coast by using a two dimensional astronomical tide and storm surge coupling mode.

In this study, Weather Research and Forecasting (WRF) model have been used for the simulation of minimum central pressure, the highest persistent wind and track of the cyclone and MRI operational storm surge model is used to simulate maximum storm surge. The main objective is to predict storm surge using WRF model simulated data and IMD estimated data as input files.

\section{Data Used and Model Description}

\subsection{WRF model}

Data used: The National Centre for Environmental Prediction (NCEP) high resolution Global Final (FNL) analysis data on $1.0^{\circ} \times 1.0^{\circ}$ grids which cover the whole world each 6hourly has been taken as initial and lateral boundary conditions for the WRF model.

Model description: WRF model is a Numerical Weather Prediction (NWP) system which is the composition of some entirely compressible non-hydrostatic equations with dissimilar predictive variables is considered to assist both atmospheric research and operational predicting desires. The development of WRF is the joint effort by several organizations to construct a future-generation mesoscale prediction model. Among them, the National Center for Atmospheric Research (NCAR) and Mesoscale and Microscale Meteorology (MMM) division makes a best combined effort to develop this model. The model assists an extensive variety of meteorological uses through scales from tens to thousands of kilometers [25]. There are different types of physics option included in this model but here we have used WRF Double-Moment 6-class (WDM6) microphysics scheme [26], Kain-Fritsch (KF) cumulus parameterization scheme [27] and Yonsei State University (YSU) Planetary Boundary Layer (PBL) scheme [28]. The summery of WRF model configuration is given in Table 1.

Table 1. WRF model and domain configuration.

\begin{tabular}{|c|c|c|c|}
\hline Dynamics & Non-hydrostatic & Time Integration & $3^{\text {rd }}$ order Runge-Kutta \\
\hline Number of Domain & 1 & $\begin{array}{l}\text { Spatial differencing } \\
\text { scheme }\end{array}$ & $\begin{array}{l}6^{\text {th }} \text { order centered } \\
\text { differencing }\end{array}$ \\
\hline Domain center & $\left(17.5^{\circ} \mathrm{N}, 87.5^{\circ} \mathrm{E}\right)$ & Initial conditions & $\begin{array}{l}\text { Three dimensional real- } \\
\text { data }\left(\text { FNL: } 1^{\circ} \times 1^{\circ}\right)\end{array}$ \\
\hline $\begin{array}{l}\text { Horizontal grid } \\
\text { distance }\end{array}$ & $9 \mathrm{~km}$ & $\begin{array}{l}\text { Microphysics } \\
\text { scheme }\end{array}$ & WDM-6 \\
\hline Vertical coordinates & $\begin{array}{l}\text { Terrain-following } \\
\text { hydrostatic-pressure }\end{array}$ & $\begin{array}{l}\text { Cumulus physics } \\
\text { scheme }\end{array}$ & Kain-Fritsch (KF) \\
\hline $\begin{array}{l}\text { Number of grid } \\
\text { points }\end{array}$ & $\begin{array}{l}\text { West-East } 100 \text { points, } \\
\text { South- North } 100 \text { points. }\end{array}$ & $\begin{array}{l}\text { PBL } \\
\text { parameterization }\end{array}$ & $\begin{array}{l}\text { Yonsei State University } \\
\text { scheme (YSU) }\end{array}$ \\
\hline Run time (72 h) & $\begin{array}{l}\text { 00Z UTC of } 19^{\text {th }} \text { May } 2016 \text { to } \\
\text { 00Z UTC of } 22^{\text {nd }} \text { May } 2016\end{array}$ & Land surface & $\begin{array}{l}5 \text { Layer thermal diffusion } \\
\text { Scheme }\end{array}$ \\
\hline Map projection & Mercator & Radiation scheme & RRTM for long wave \\
\hline Horizontal grid & Arakawa C-grid & Surface layer & $\begin{array}{l}\text { Monin-Obukhov } \\
\text { similarity theory }\end{array}$ \\
\hline
\end{tabular}




\subsection{MRI storm surge model}

Data used: The input file of this model contains cyclones latitudes, longitudes, radius of maximum wind, minimum sea level pressure, drag coefficient and atmospheric pressure.

Model description: The Meteorological Research Institute (MRI) storm surge model was advanced by Japan Meteorological Agency (JMA). JMA controls mainly two storm surge models, one for the region of Japan and other for the Asian region. JMA started improvement of the storm surge model for Asian province in 2010 after receiving a request from the World Meteorological Organization (WMO) executive council $\left(6^{\text {th }}\right.$ session, June 2008). The tide observation data and sea bathymetry data was provided by Typhoon Committee Members. First horizontal distribution maps of predicted storm surge was published on JMA's Numerical Typhoon website on June 2011 [29]. The computational mechanism of the storm surge model for the Asian region is established on the basis of one scenario by Global Spectral Model (GSM). Though, deterministic prediction is inadequate for the hazard controlling. Thus, JMA made an idea to incorporate multi scenario forecasts in the storm surge model for the Asian region. These scenarios are obtained from JMA Typhoon Ensemble Predictions System (TEPS) with cluster analysis [30]. The Bangladesh Meteorological Department (BMD) introduced the new version of the MRI storm surge model by Mr. Nadao Kohno, Marine Modeling Unit, the Office of Marine Prediction, Marine Division, Global Environment and Marine Department, JMA. The summery of MRI operational storm surge model configuration is given in Table 2 .

Table 2. MRI operational storm surge model and domain configuration.

\begin{tabular}{llll}
\hline Model & 2- dimensional linear model & Time step & 8 seconds \\
\hline Grid & Lat-Lon Arakawa-C grid & Initial time & $00,06,12,18$ (UTC) \\
Region & $8.5-23.5^{\circ} \mathrm{N}, 80-100^{\circ} \mathrm{E}$ & Forecast time & 72 hours \\
Resolution & 2-min mesh & Member & 1 member \\
Run & 4 times/day (6 hourly) & Forcing & GSM, GPV (20 km) \\
\hline
\end{tabular}

\section{Results and Discussion}

\subsection{Analysis of intensity}

To measure the intensity of the tropical cyclone, minimum sea level pressure is very important. From the Fig. 1, the variation of simulated minimum central pressure (MCP) and the estimated minimum central pressure (ECP) [31] are shown for cyclonic storm Roanu. Initially the ECP and simulated MCP decrease with time, after sometimes the system attain peak intensity just before the landfall and then again ECP and simulated MCP increase with time. The minimum central pressure simulated by WRF model is found around $941 \mathrm{hPa}$ at $12 \mathrm{Z}$ UTC of $21^{\text {st }}$ May and estimated central pressure is $983 \mathrm{hPa}$ by IMD between $21 Z$ UTC of $20^{\text {th }}$ May to 09Z UTC of $21^{\text {st }}$ May. Therefore, the WRF model has predicted the intensification of the system 15 hours in delay and overestimates the pressure drop by $42 \mathrm{hPa}$. 


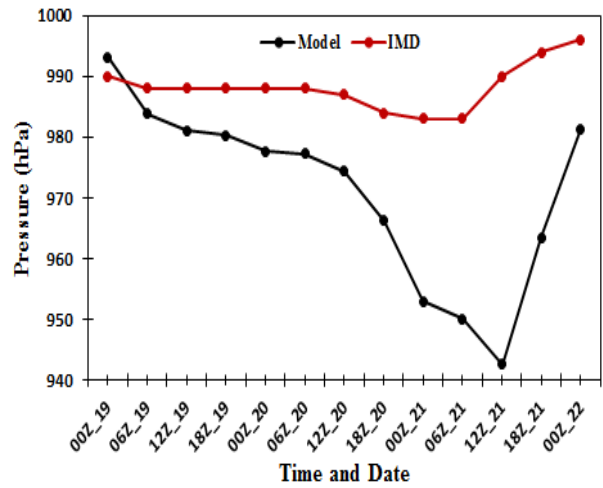

Fig. 1. Variation of the model simulated and IMD estimated central pressure with time.

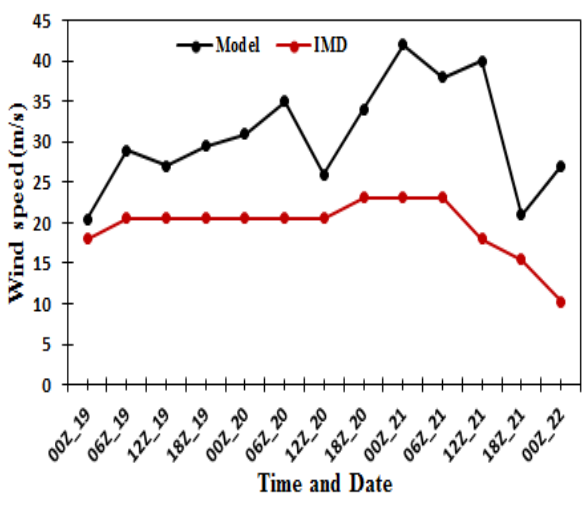

Fig. 2. Comparison of WRF model simulated and IMD estimated MWS with time.

Fig. 2 shows the time variation of maximum wind speed (MWS) simulated by the WRF model and estimated by IMD. The model simulated wind speed is at the standard meteorological height of $10 \mathrm{~m}$. From the figure it is found that, the model simulated MWS is greater than the estimated wind speed through the entire time of simulation. The simulated MWS is $40 \mathrm{~ms}^{-1}$ at $12 \mathrm{Z}$ UTC of $21^{\text {st }}$ May but the estimated maximum sustained wind speed by IMD is $23 \mathrm{~ms}^{-1}$ between 18Z UTC of $20^{\text {th }}$ May to 06Z UTC of $21^{\text {st }}$ May and maintained its speed up to 0900 UTC of $21^{\text {st }}$ May. Model obviously overestimates the MWS by nearly $17 \mathrm{~ms}^{-1}$. After that, both simulated and estimated wind speed gradually decrease with time due to land interaction near the landfall time The model simulated maximum wind speed is 15 hours delay than estimation. Again, the model simulated system retains its intensity only for $06 \mathrm{~h}$ but estimation shows $15 \mathrm{~h}$ of peak intensity.
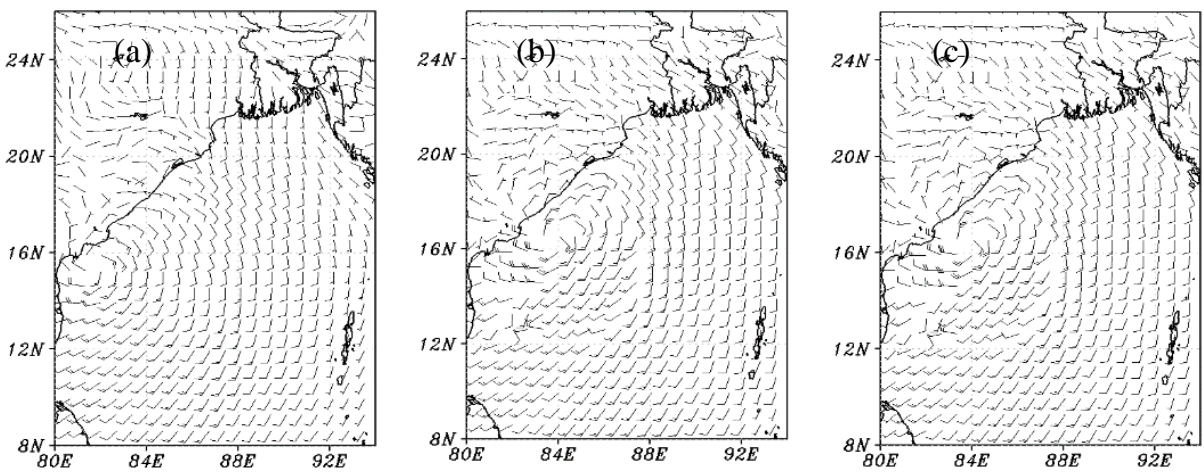

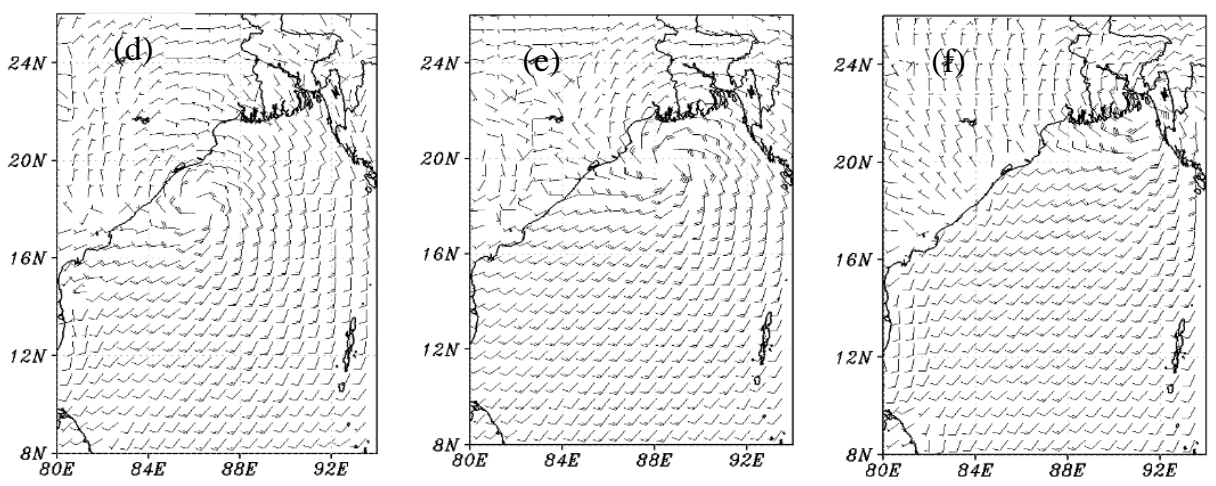

Fig. 3. Distributions of wind at the surface level at (a) 00Z UTC of $19^{\text {th }}$, (b) $12 Z$ UTC of $19^{\text {th }}$, (c) $00 Z$ UTC of $20^{\text {th }}$, (d) $12 Z$ UTC of $20^{\text {th }}$, (e) 00Z UTC of $21^{\text {st }}$ and (f) $12 Z$ UTC of $21^{\text {st }}$ May.

\subsection{Distributions of wind and pressure}

Distributions of the wind field at different time at the surface level (10 meter from the sea level) of the cyclone Roanu are shown in the Fig. 3 (a-f). Distributions include at $00 \mathrm{Z}$ UTC of $19^{\text {th }}, 12 \mathrm{Z}$ UTC of $19^{\text {th }}, 00 Z$ UTC of $20^{\text {th }}, 12$ Z UTC of $20^{\text {th }}, 00 Z$ UTC of $21^{\text {st }}$ and $12 Z$ UTC of $21^{\text {st }}$ May 2016. Highly asymmetric wind distribution found at every stage of the cyclone. At $00 \mathrm{Z}$ UTC of $19^{\text {th }}$ May, strong wind bands are found in the south east sector of the system. In the core region of the cyclone minimum wind speed is found. A Similar pattern is also seen for 00Z UTC of $20^{\text {th }}, 21^{\text {st }}$ and $12 Z$ UTC of $21^{\text {st }}$ May. At $12 Z$ UTC of $21^{\text {st }}$ May strong wind is found around the center of the cyclone. MWS is found at the time of maximum intensity. After the landfall of the cyclone, wind speed decreases with time due to landmass friction.

The distributions of simulated sea level pressure by WRF model are shown in Fig. 4 (a-f) at 00Z UTC of $19^{\text {th }}, 12 \mathrm{Z}$ UTC of $19^{\text {th }}$, 00Z UTC of $20^{\text {th }}, 12 \mathrm{Z}$ UTC of $20^{\text {th }}$, 00Z UTC of $21^{\text {st }}$ and $12 Z$ UTC of $21^{\text {st }}$ May 2016. These figures show that the system changes its position with time and the central pressure decreases. From these Fig. 4(a-f), it is clear that the movement of the system is northeastward direction and at 12Z UTC of $21^{\text {st }}$ May it crossed over the coastal area of Bangladesh. The isobaric lines are circularly arranged around the center of TC and there are some asymmetry properties in the outer periphery. At the mature stage of the system at $12 \mathrm{Z}$ UTC of $21^{\text {st }}$ May the center of the cyclone located $21.95^{\circ} \mathrm{N}$ and $91.34^{\circ} \mathrm{E}$ (Fig. 4f) and then after few hours' system crossed over Bangladesh. 

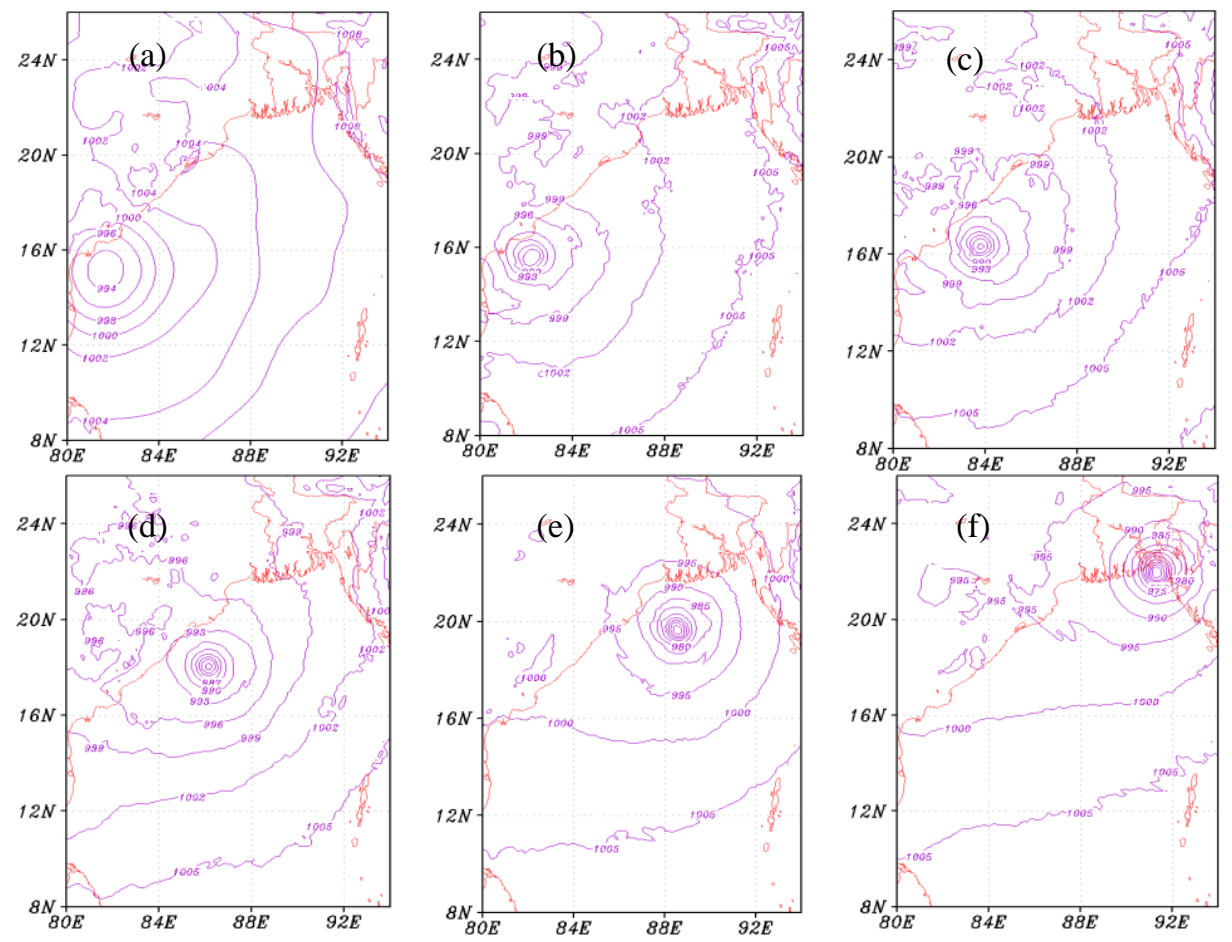

Fig. 4. Distributions of mean sea level pressure at (a) $00 Z$ UTC of $19^{\text {th }}$, (b) $12 Z$ UTC of $19^{\text {th }}$, (c) $00 Z$ UTC of $20^{\text {th }}$, (d) $12 Z$ UTC of $20^{\text {th }}$, (e) 00Z UTC of $21^{\text {st }}$ and (f) $12 Z$ UTC of $21^{\text {st }}$ May 2016.

\subsection{Track pattern analysis}

Track data is very important to simulate the storm surge for any cyclonic storm, because latitude and longitude of any cyclone are a fundamental requirement for the MRI storm surge model to simulate the storm surge perfectly. Fig. 5(a) represents the comparison between the models simulated track and observed track of cyclone Roanu. Both model and estimated track pattern are plotted in the same figure. The track forecast of Roanu is $72 \mathrm{~h}$ based on the initial field 0000 UTC of $19^{\text {th }}$ May. The model is able to produce northeastward movement of the system. Fig. 5(a) shows that both the model and observed track are parallel to each other. The model simulated landfall point $\left(21.5^{\circ} \mathrm{N}, 91.8^{\circ} \mathrm{E}\right)$ is slightly deviated to the southeastward direction from the observed landfall point $\left(22.6^{\circ} \mathrm{N}\right.$, 91.6 $\left.{ }^{\circ} \mathrm{E}\right)$. Variation of Track error with time is shown in Fig. 5(b). Initially, track error has been found minimum but at 06Z UTC of $20^{\text {th }}$ May to 06Z of $21^{\text {st }}$ May track errors have been found maximum. Overall, average track error is found $121.24 \mathrm{~km}$ which is allowable. 

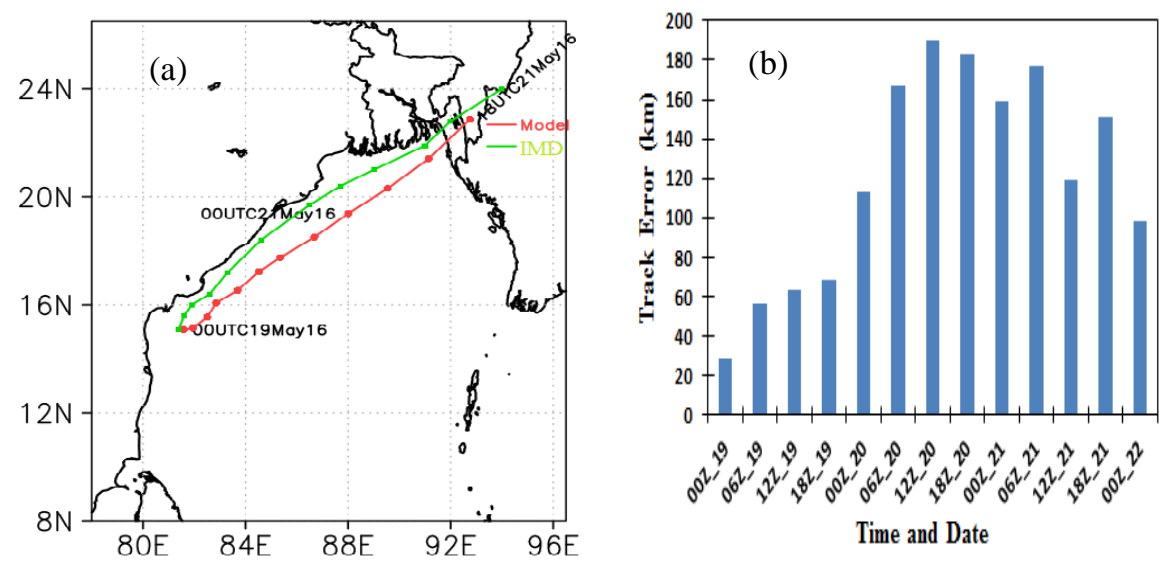

Fig. 5. (a) Comparison of model simulated track and IMD estimated track (b) Track error versus time graph.
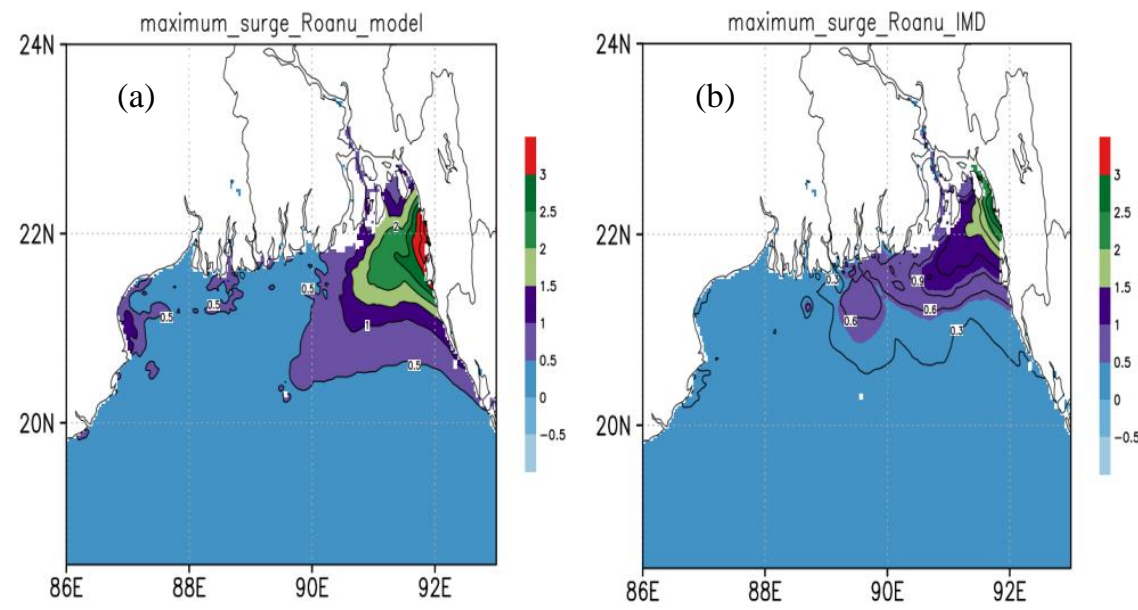

Fig. 6. Maximum storm surge distribution of cyclone Roanu by the MRI storm surge model using (a) WRF model simulated data and (b) IMD estimated data as input file.

\subsection{Analysis of maximum storm surge by MRI model}

An input file is needed to simulate maximum storm surge for any cyclone by any parametric model. MRI storm surge model is one of a parametric model, that's why input file is needed. The input file includes forecast time (UTC), latitude, longitude, minimum central pressure (Pcenter), radius of maximum wind, drag coefficient (Co-ef) and atmospheric pressure (Pfar). In this research, MRI model run the input data from $00 \mathrm{Z}$ UTC of $21^{\text {st }}$ May to 00Z UTC of $22^{\text {nd }}$ May. From IMD report, the system made landfall at $10 \mathrm{Z}$ UTC of $21^{\text {st }}$ May. Fig. 6(a-b) shows generated maximum surge height by the MRI storm surge model. From the following figure maximum surge height using WRF simulated data is found approximately $3 \mathrm{~m}$ near the south-east coast of Bangladesh and 
using IMD estimated data maximum surge is found $2.5 \mathrm{~m}$. Maximum surge height reported of cyclone Roanu is $2 \mathrm{~m}$ [32]. Thus, it can be decided that the MRI storm surge model is overestimated the storm surge for both input file. This overestimation is expected because the WRF model simulated minimum central pressure is very low compared to the IMD estimated minimum central pressure.
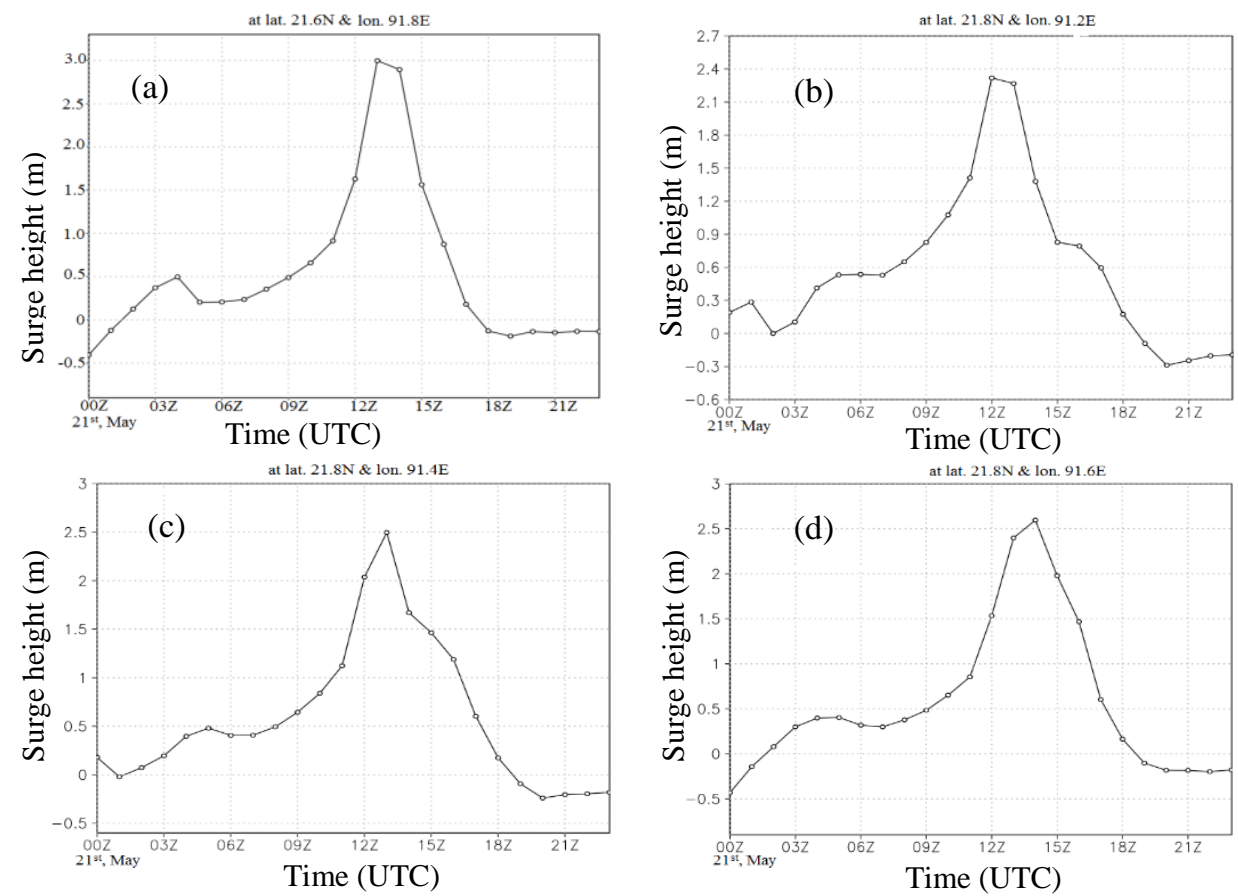

Fig. 7. Time series of storm surge at : (a) $21.6^{\circ} \mathrm{N}, 91.8^{\circ} \mathrm{E}$, (b), $21.8^{\circ} \mathrm{N}, 91.2^{\circ} \mathrm{E}$, (c) $21.8^{\circ} \mathrm{N}, 91.4^{\circ} \mathrm{E}$ and (d) $21.8^{\circ} \mathrm{N}, 91.6^{\circ} \mathrm{E}$ using WRF model output as input data by MRI storm surge model.

\subsection{Average surge calculation around the landfall point}

Figs. 7(a-d) and 8(a-d) represent the time variation of storm surge at different locations around the landfall point of the TC Roanu. WRF model simulated data (landfall point $21.5^{\circ} \mathrm{N}, 91.8^{\circ} \mathrm{E}$ ) is used to evaluate the surge height in Fig. 7 and IMD estimated (landfall point $22.6^{\circ} \mathrm{N}, 91.6^{\circ} \mathrm{E}$ ) data is used in Fig. 8. The maximum surge heights at different locations are shown in Table 3 . Since maximum surge height is associated along the right part of a cyclone, we consider four different locations at right of landfall point. The average values for both the input data are also calculated. The average maximum surge height for the TC Roanu for WRF data and IMD estimated data are respectively 2.6 and $2.08 \mathrm{~m}$. Therefore MRI storm surge model shows higher surge height for WRF model data than that of IMD. 
Table 3. Average surge height calculation.

\begin{tabular}{llllll}
\hline \multicolumn{2}{l}{ Input file: WRF model data } & \multicolumn{4}{l}{ Input file: IMD estimated data } \\
\hline $\begin{array}{l}\text { Location } \\
\left({ }^{\circ} \mathrm{N},{ }^{\circ} \mathrm{E}\right)\end{array}$ & $\begin{array}{l}\text { Maximum } \\
\text { surge }(\mathrm{m})\end{array}$ & $\begin{array}{l}\text { Average } \\
\text { surge }(\mathrm{m})\end{array}$ & $\begin{array}{l}\text { Location } \\
\left({ }^{\circ} \mathrm{N},{ }^{\circ} \mathrm{E}\right)\end{array}$ & $\begin{array}{l}\text { Maximum } \\
\text { surge }(\mathrm{m})\end{array}$ & $\begin{array}{l}\text { Average } \\
\text { surge }(\mathrm{m})\end{array}$ \\
\hline $21.6,91.8$ & 3.0 & $2.6 \pm 0.15$ & $21.8,91.8$ & 1.65 & $2.08 \pm 0.14$ \\
$21.8,91.2$ & 2.3 & & $22.0,91.8$ & 2.20 & \\
$21.8,91.4$ & 2.5 & & $22.4,91.4$ & 2.25 & \\
$21.8,91.6$ & 2.6 & & $22.6,91.6$ & 2.25 & \\
\hline
\end{tabular}
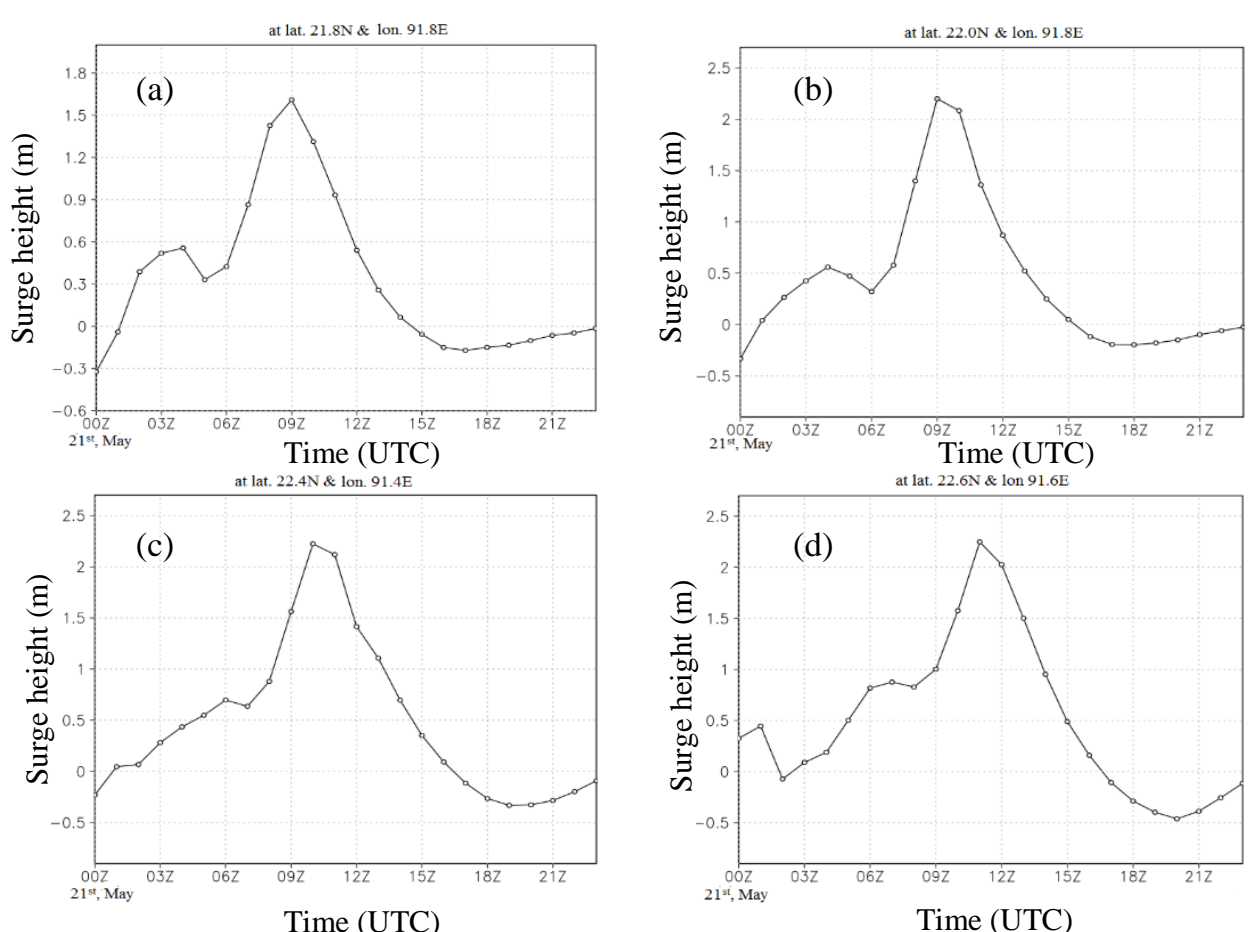

Fig. 8. Time series of storm surge at : (a) $21.8^{\circ} \mathrm{N}, 91.8^{\circ} \mathrm{E}$, (b) $22.0^{\circ} \mathrm{N}, 91.8^{\circ} \mathrm{E}$, (c) $22.4^{\circ} \mathrm{N}, 91.4^{\circ} \mathrm{E}$ and (d) $21.6^{\circ} \mathrm{N}, 91.6^{\circ} \mathrm{E}$ using IMD estimated data as input by MRI storm surge model.

\subsection{Distributions of storm surge}

From WRF model simulated track data, the cyclone Roanu made landfall in between $13 Z$ UTC of $21^{\text {st }}$ May to14Z UTC of $21^{\text {st }}$ May. For this reason, distributions of storm surges are taken from 11Z UTC of $21^{\text {st }}$ May to $14 Z$ UTC of $21^{\text {st }}$ May. From the following Fig. 9(a-d) show the distributions of the storm surges in four different times. At $11 Z$ UTC of $21^{\text {st }}$ May (Fig. 9a) cyclone lay centered over northeast Bay and adjoining south western coastal region and maximum surge at this time is about $1.5 \mathrm{~m}$. The system move northeasterly direction and approximately $2 \mathrm{~m}$ surge height is found at $12 \mathrm{Z}$ UTC of $21^{\text {st }}$ May and 13ZUTC of $21^{\text {st }}$ which are shown in Figs. 9b and 9c respectively. Surge height 
is increased up to the landfall of the system and approximately $3 \mathrm{~m}$ surge height is found at 14 Z UTC (Fig. 9d).
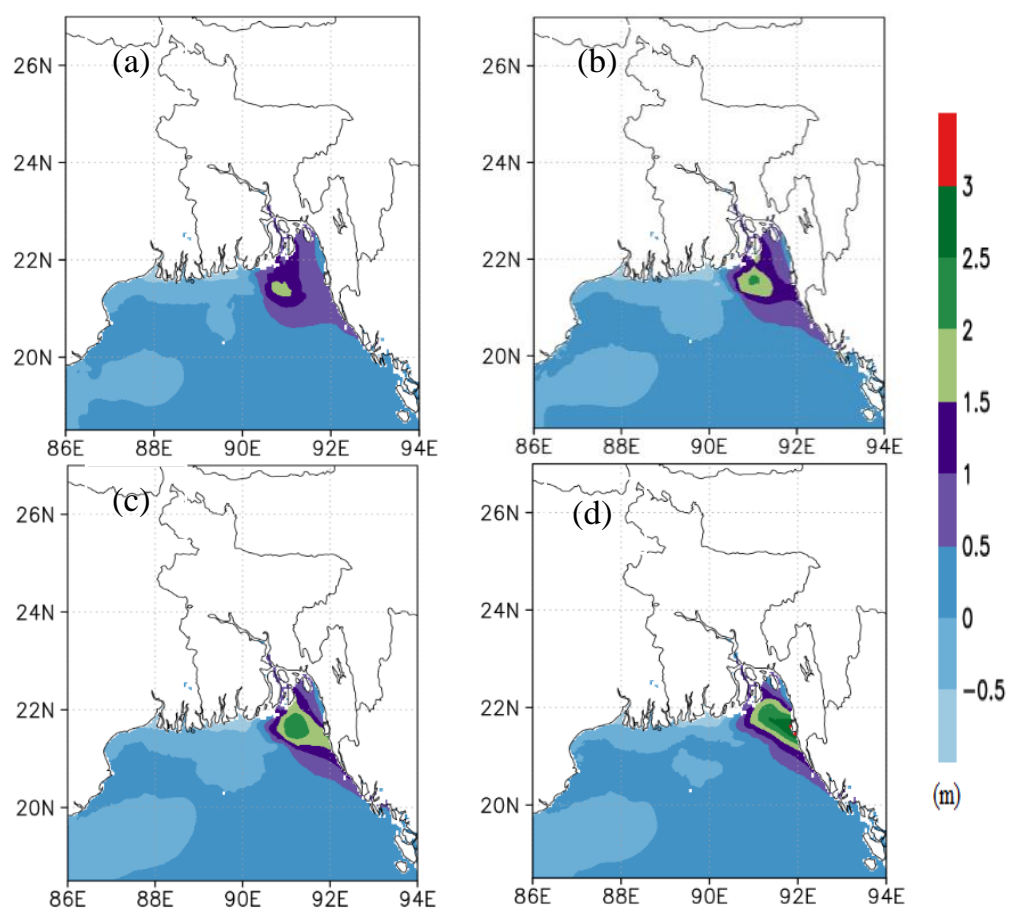

Fig. 9. Distribution of storm surge by the MRI storm surge model using WRF simulated data as input at (a) 11Z UTC, (b) 12Z UTC, (c) 13Z UTC and (d) 14Z UTC $21^{\text {st }}$ May 2016.

Distributions of the storm surges in four different times using IMD estimated track data as input file by MRI storm surge model are given the following Fig. 10(a-d). At 11Z UTC of $21^{\text {st }}$ May cyclone lay centered at lat. $22.8^{\circ} \mathrm{N} \&$ lon. $92.0^{\circ} \mathrm{E}$ and maximum surge at this time is found 1-1.5 m (Fig. 10a). With the passage of time, the system crossed the southeastern coastal region of Bangladesh and at $12 \mathrm{Z}$ UTC \& $13 \mathrm{Z}$ UTC of $21^{\text {st }}$ May maximum surge height is found approximately $2 \mathrm{~m}$ which is shown in Fig. $10 \mathrm{~b}$ and $10 \mathrm{c}$ respectively. The maximum surge height is found almost $2.5 \mathrm{~m}$ at $14 \mathrm{Z}$ UTC of $21^{\text {st }}$ May (Fig. 10d) which is greater than that of $11 \mathrm{Z}$ UTC of $21^{\text {st }}$ May. 

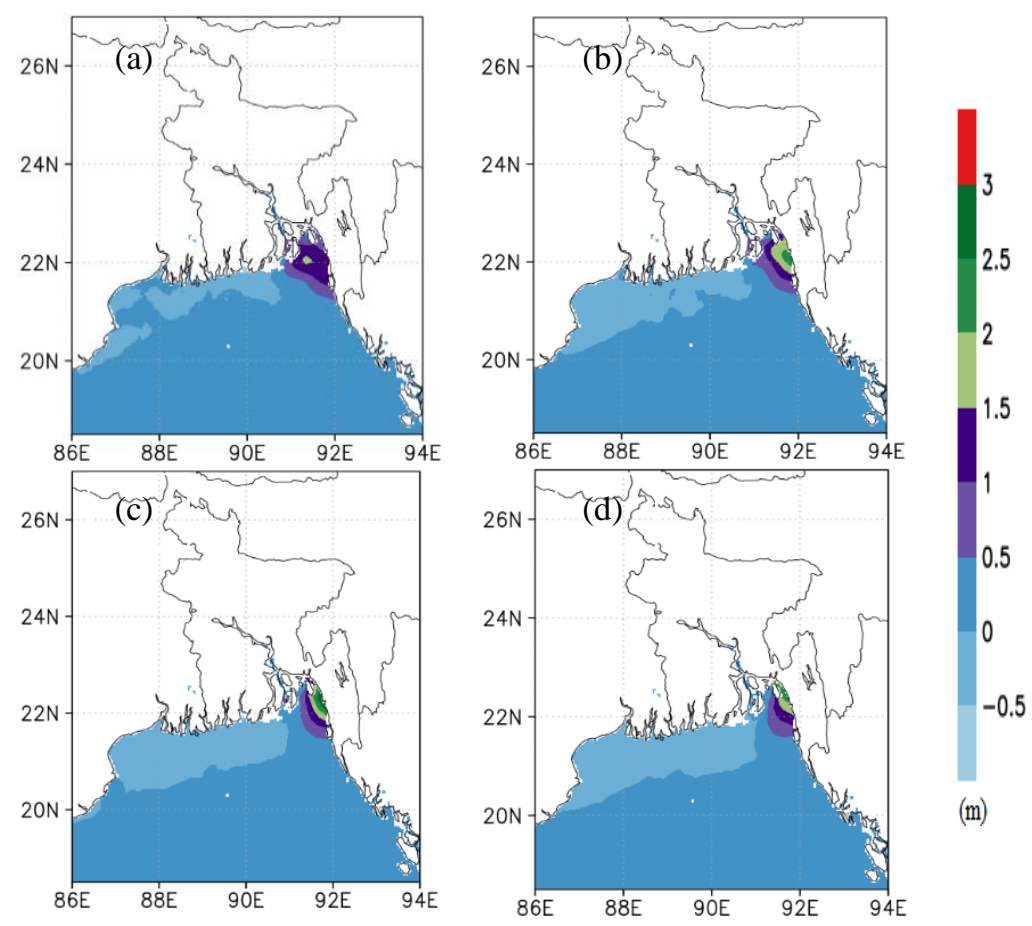

Fig. 10. Distribution of storm surge by MRI storm surge model using IMD estimated data as input at (a) 11 Z UTC, (b) $12 \mathrm{Z} \mathrm{UTC,} \mathrm{(c)} \mathrm{13Z} \mathrm{UTC} \mathrm{and} \mathrm{(d)} 14 \mathrm{Z}$ UTC $21^{\text {st }}$ May 2016.

\section{Conclusion}

From the above discussions, the following conclusions have been made:

- The WRF model simulated minimum central pressure for cyclone Roanu is found 941 $\mathrm{hPa}$ and IMD estimated minimum central pressure is $983 \mathrm{hPa}$.

- The model simulated maximum wind speed for cyclone Roanu is found $40 \mathrm{~ms}^{-1}$. IMD estimated maximum surface wind speed is $23 \mathrm{~ms}^{-1}$. The model overestimated maximum surface wind by $17 \mathrm{~ms}^{-1}$. The observed central pressure and wind speed indicates a cyclonic storm intensity, but the model produces a very severe cyclonic storm intensity [33].

- The model simulated track is almost parallel to the IMD estimated track and average track error is found $121.24 \mathrm{~km}$.

- The MRI model simulated the average surge height around the landfall point using WRF simulated data and IMD estimated data as input are found 2.6 and $2.08 \mathrm{~m}$ respectively.

- The MRI model simulated storm surge height using the WRF model simulated data is found $3 \mathrm{~m}$ and using IMD estimated data it is approximately $2.5 \mathrm{~m}$. 


\section{Acknowledgments}

The authors are grateful to National Center for Atmospheric Research (NCAR) and National Center for Environmental Prediction (NCEP) for providing WRF model and data respectively. The authors also grateful to Japan Meteorological Agency for providing MRI operational storm surge model. We are thankful to Bangladesh Meteorological Department (BMD) and India Meteorological Department for estimated data to validate our result.

\section{References}

1. S. Mohandas and R. Ashrit, Nat. Hazards 73, 213 (2014). https://doi.org/10.1007/s11069-013-0824-6

2. K. Saito, T. Kuroda, M. Kunii, and N. Kohno, J. Meteorolog. Soc. Jap. 88, 547 (2010). https://doi.org/10.2151/jmsj.2010-316

3. M. A. K. Mallik, M. N. Ahsan, and M. A. M. Chowdhury, Am. J. Mar. Sci. 3, 11 (2015).

4. M. A. E. Akhter, M. M. Alam, and M. A. K. Mallik, J. Sci. Res. 8, 129 (2016). http://dx.doi.org/10.3329/jsr.v8i2.25217

5. I. Jain, P. Chittibabu, N. Agnihotri, S. K. Dube, P. C. Sinha, and A. D. Rao, Natural Hazards 39, 71 (2006). https://doi.org/10.1007/s11069-005-3176-Z

6. G. O. P. Obasi, Bull. Am. Meteorolog. Soc. 75, 1655 (1994). https://doi.org/10.1175/1520-0477(1994)075<1655:WRITID>2.0.CO;2

7. S. K. Dube, I. Jain, A. D. Rao, and T. S. Murty, Nat. Hazards 51, 3 (2009). https://doi.org/10.1007/s11069-009-9397-9

8. T. Kuroda, K. Saito, M. Kunii, and N. Kohno, J. Meteorolog. Soc. Jap. 88, 521 (2010). https://doi.org/10.2151/jmsj.2010-315

9. H. F. Needham, B. D. Keim, and D. Sathiaraj, Rev. Geophys. 53, 545 (2015). https://doi.org/10.1002/2014RG000477

10. M. I. Ali, A. Imran, I. M. Syed, M. J. Islam, and M. A. K. Mallik, J. Eng. Sci. 9, 33 (2018).

11. N. Kohno, S. Dube, M. Entel, S. Fakhruddin, D. Greenslade, M. D. Leroux, and N. Thuy, Trop. Cyclone Res. Rev. 7, 128 (2018). https://doi.org/10.6057/2018TCRR02.04

12. S. K. Dube, P. C. Sinha, A. D. Rao, and G. S. Rao, Appl. Mathemat. Modell. 9, 289 (1985). https://doi.org/10.1016/0307-904X(85)90067-8

13. S. K. Dube, A. D. Rao, P. C. Sinha, T. S. Murty, and N. Bahulayan, Mausam 48, 283 (1997).

14. P. C. Sinha, S. K. Dube, G. D. Roy, and S. Jaggi, Int. J. Numeric. Methods Fluids 6, 305 (1986). https://doi.org/10.1002/fld.1650060505

15. P. C. Sinha, Y. R. Rao, S. K. Dube, and T. S. Murty, Marine Geodesy 20, 341 (1997). https://doi.org/10.1080/01490419709388114

16. R. A. Flather, J. Phy. Oceanography 24, 172 (1994). https://doi.org/10.1175/1520-0485(1994)024<0172:ASSPMF>2.0.CO;2

17. A. Ali, H. Rahman, S. Sazzad, and H. Chowdhury, Mausam 48, 531 (1997). http://metnet.imd.gov.in/mausamdocs/14845.pdf

18. J. A. As-Salek, Monthly Weather Rev. 125, 1638(1997). https://doi.org/10.1175/1520-0493(1997)125<1638:NSITME>2.0.CO;2

19. J. A. As-Salek, J. Phys. Oceanography 28, 227 (1998). https://doi.org/10.1175/1520-0485(1998)028<0227:CTAFEO>2.0.CO;2

20. F. Jakobsen, M. H. Azam, M. M. Z. Ahmed, and M. Mahboob-ul-Kabir, Coastal Eng. J. 48, 295 (2006). https://doi.org/10.1142/S057856340600143X

21. S. K. Debsarma, Marine Geodesy 32, 178 (2009). https://doi.org/10.1080/01490410902869458

22. C. Shaji, S. K. Kar, and T. Vishal, Ind. J. Geo-Marine Sci. 43, 125 (2014). 
23. J. H. Zheng, S. Sang, J. C. Wang, C. Y. Zhou, and H. J. Zhao, Water Sci. Eng. 10, 2 (2017). https://doi.org/10.1016/j.wse.2017.03.004

24. J. H. Zheng, J. C. Wang, C. Y. Zhou, H. J. Zhao, and S. Sang, Water Sci. Eng. 10, 8 (2017). https://doi.org/10.1016/j.wse.2017.03.011

25. ARW Version 3.8.1; Modeling Systems User Guide, January 2016. http://www2.mmm.ucar.edu/wrf/users/docs/user_guide_V3.8/ARWUsersGuideV3.8.pdf

26. K. S. S. Lim and S. Y. Hong, Monthly Weather Rev. 138, 1587 (2010). https://doi.org/10.1175/2009MWR2968.1

27. J. S. Kain, J. Appl. Meteorol. 43, 170 (2004). https://doi.org/10.1175/1520-0450(2004)043<0170:TKCPAU>2.0.CO;2

28. S. Y. Hong, Y. Noh, and J. Dudhia, Monthly Weather Rev. 134, 2318 (2006). https://doi.org/10.1175/MWR3199.1

29. H. Hasegawa, N. Kohno, and H. Hayashibara, RSMC Tokyo-Typhoon Center Technical Rev. 14, 13 (2012).

https://www.jma.go.jp/jma/jma-eng/jma-center/rsmc-hp-pub-eg/techrev/text14-2.pdf

30. H. Hasegawa, N. Kohno, and M. Itoh, Development of Storm Surge Model in Japan Meteorological Agency (Office of Marine Prediction, Japan Meteorological Agency, 2015). http://www.waveworkshop.org/14thWaves/Papers/JCOMM_2015_J4.pdf

31. Cyclonic Storm 'ROANU' Over the Bay of Bengal (17-22 May, 2016): A Report; Cyclone Warning Division India Meteorological Department (New Delhi, June, 2016). http://www.rsmcnewdelhi.imd.gov.in/images/pdf/publications/preliminary-report/Roanu.pdf

32. Half a Million Flee as Cyclone Roanu Hits Bangladesh, Aljazeera, 2016. https://www.aljazeera.com > news > 2016/05

33. M. J. Islam, A. Imran, I. M. Syed, S. M. Q. Hassan, and M. I. Ali, Dhaka Univ. J. Sci. 67, 33 (2019).

http://journal.library.du.ac.bd/index.php?journal=dujs\&page=article\&op=view\&path\%5B \%5D $=1909 \&$ path\%5B $\% 5 \mathrm{D}=1759$ 